Article

\title{
Evolution of the Upper Yellow River as Revealed by Changes in Heavy-Mineral and Geochemical (REE) Signatures of Fluvial Terraces (Lanzhou, China)
}

\author{
Zhao Wang ${ }^{1,2}$ (), Haobo Zhang ${ }^{1}$, Eduardo Garzanti ${ }^{2}{ }^{(1)}$, Junsheng Nie ${ }^{1,3, *}$, Wenbin Peng ${ }^{4}$, \\ Sergio Andò ${ }^{2}$, Xiaofei Hu ${ }^{1}$, Baotian Pan ${ }^{1}$ and Katharina Pfaff ${ }^{5}$ \\ 1 Key Laboratory of Western China's Environment Systems (Ministry of Education), College of Earth and \\ Environmental Sciences, Lanzhou University, Lanzhou 730000, China; zhaowang14@lzu.edu.cn (Z.W.); \\ hbzhang17@lzu.edu.cn (H.Z.); feixhu@lzu.edu.cn (X.H.); panbt@lzu.edu.cn (B.P.) \\ 2 Laboratory for Provenance Studies, Department of Earth and Environmental Sciences, University of \\ Milano-Bicocca, 20126 Milano, Italy; eduardo.garzanti@unimib.it (E.G.); sergio.ando@unimib.it (S.A.) \\ 3 CAS Center for Excellence in Tibetan Plateau Earth Sciences, Chinese Academy of Sciences (CAS), \\ Beijing 100101, China \\ 4 School of Tourism and Resource Environment, Zaozhuang University, Zaozhuang 277160, China; \\ pengwb14@163.com \\ 5 Department of Geology and Geological Engineering, Colorado School of Mines, 1516 Illinois Street, Golden, \\ CO 80401, USA; kpfaff@mines.edu \\ * Correspondence: jnie@lzu.edu.cn
}

Received: 5 September 2019; Accepted: 28 September 2019; Published: 30 September 2019

\begin{abstract}
Despite decades of study, the factors that controlled the formation and evolution of the upper reaches of the Yellow River, including uplift of the northeastern Tibetan Plateau, Pliocene-Pleistocene climate change, and autogenetic processes are still poorly constrained. The stratigraphic record of such paleogeographic evolution is recorded in the sequence of nine terraces formed during progressive incision of the Yellow River in the last 1.7 Ma. This article investigates in detail for sediment provenance in terraces of the Lanzhou area, based on heavy-mineral and geochemical (REE) signatures. Two main provenance changes are identified, pointing each to a major paleogeographic reorganization coupled with expansion of the upper Yellow River catchment and enhanced sediment fluxes. The first change took place between the deposition of terrace T9 (formed around 1.7 Ma) and terrace T8 (formed around 1.5 Ma), when rapid fluvial incision point to tectonic control and active uplift of northeastern Tibetan Plateau. The second change took place between deposition of terrace $\mathrm{T} 4$ (formed around 0.86 Ma) and terrace T3 (formed around 0.14 Ma), during a period of low incision rates and notably enhanced sediment fluxes as a response to enhanced East Asian Summer Monsoon and consequently increased precipitations, pointing instead chiefly to climatic control.
\end{abstract}

Keywords: provenance analysis; tectonic versus climatic control; early-middle Pleistocene transition; Yellow River terraces; Lanzhou (northern China)

\section{Introduction}

The Yellow River is the sixth longest river and carries the highest sediment load in the world [1,2]. The upper course of the Yellow River drains the central and northeastern Tibetan Plateau, and reconstructing its origin and early history is key to understanding the relationship between fluvial incision, climate variation, and basement uplift [3-9]. In the northeastern Tibetan Plateau, the Yellow River is deeply incised into a series of intermontane basins and tectonic ranges. The valley contains a series of fluvial terraces, which preserve the record of successive stages of plateau uplift and climatic 
change [10]. Based on the chronological sequence of the terraces, the Yellow River system was interpreted to have been formed since the middle Pleistocene as a response either to the accelerated tectonic uplift of the northeastern Tibetan Plateau $[3,4,6,7,10,11]$, or to climatically-driven expansion of lake systems breaching topographic barriers [12-14].

Previous provenance studies of Yellow River sediments emphasized mainly the spatial differentiation among upper, middle, and lower modern fluvial reaches using zircon and heavy-mineral data $[9,15-20]$. However, there are few studies using heavy-mineral data to study paleo-drainage changes of the upper Yellow River on time scale. Zircon U-Pb geochronology was used to infer provenance of the upper Yellow River terraces in the Lanzhou area [18,21], but based on a limited number of grains ( 100) per sample. In the complex northeastern Tibetan Plateau area, a considerably higher number of valid zircon ages need to be obtained ( $\geq 250$ per sample) $[22,23]$ in order to reliably identify subtle provenance differences in the dataset.

To improve our understanding of the evolution of the upper Yellow River catchment and to explain the role of several interconnected factors-including regional topography, tectonic deformation, and climatic change-we have carried out detailed provenance analysis of the Yellow River terraces well exposed in the Lanzhou area based on heavy-mineral and geochemical data. Heavy mineral compositions are often used to infer sedimentary provenance. Many heavy mineral species are found in sediment or sedimentary rocks, many of which are diagnostic sedimentary source indicators [24]. Differences in heavy mineral assemblages can often be used to differentiate different sediment transport routes [25]. Rare earth elements (REE) are generally regarded as useful in identifying the origin and formation mechanism of source rocks [26] and have been increasingly used in recent years as provenance tracers, because REE are less fractionated during the progress of weathering, transport, and sedimentation [27-31]. In order to increase throughput, we relied on the QEMSCAN (Quantitative Evaluation of Minerals by Scanning Electron Microscopy) method for heavy-mineral analyses, whereas geochemical signatures were determined by LA-ICP-MS (laser ablation and Inductively coupled plasma mass spectrometry).

\section{Yellow River Terraces in the Lanzhou Area}

The Lanzhou Basin, located at the northeastern edge of the actively uplifting Tibetan Plateau, is part of the larger Longzhong Basin crossed by the upper Yellow River [32,33] (Figure 1) and including deposits of Late Cretaceous to Cenozoic age [34]. The Lanzhou basin, a graben-like structure 5-10 km wide and extending over a length of $40 \mathrm{~km}$ from Hutouya in the west-northwest to Sangyuanxia in the east-southeast, and it is divided into a western sub-basin delimited to the north by the Jinchengguan fault and an eastern sub-basin delimited by the Baitashan and Leitanhe fault in the west and by the Gaolan Mountains in the south [35] (Figure 1b).

Along the northern margin of the eastern Lanzhou sub-basin, the stepwise incision of the Yellow River has formed nine terraces (from the oldest T9 at the top to the youngest T1 at the base) (Figure 1a,b). Terraces T9 to T2 are strath terraces covered by loess-paleosol of different thickness and beveled across either Cretaceous-Cenozoic sandstone or Precambrian basement [10,11] (Figure 1c). The highest terrace T9, studied in the Yaogou section, lies $333 \mathrm{~m}$ above the modern river, is based on red Cenozoic sandstone, and consists of $10 \mathrm{~m}$ of fluvial gravel overlain by $22 \mathrm{~m}$ of fluvial sand and clay [36-38]. Terrace T8, studied in the Jiuzhoutai section, lies $100 \mathrm{~m}$ below T9, is also based on red Cenozoic sandstone, and consists of 2-3 m of fluvial gravel [11]. Terrace T7, studied in the Dunwashan section, lies $140 \mathrm{~m}$ above the modern river and consists of $6 \mathrm{~m}$ of fluvial gravel overlain by $12 \mathrm{~m}$ of overbank deposits. Terrace T6, exposed along the northern margin of the eastern Lanzhou basin and studied in the Dalanggou section, lies $127 \mathrm{~m}$ above the modern river and consists of 3-4 m of fluvial gravel overlain by $18 \mathrm{~m}$ of fluvial sand. Terrace T5, exposed in a narrow strip between the Xiaoshagou and Xiaogou sections, lies $108 \mathrm{~m}$ above the modern river consists of 3-4 m of fluvial gravel overlain by $\sim 11 \mathrm{~m}$ of interchannel sand. Terrace T4, exposed almost along the entire length of the Lanzhou basin and studied in the Zaoshugou section, lies $99 \mathrm{~m}$ above the modern river and consists of 4-6 $\mathrm{m}$ of fluvial 
gravel overlain by 6-10 $\mathrm{m}$ of fluvial sand. The most widely exposed and preserved best terrace T3 lies $60 \mathrm{~m}$ above the modern river and comprises of 5-7 $\mathrm{m}$ of fluvial gravel overlain by $10 \mathrm{~m}$ of fluvial sand in the Baitashan section. The lowest strath terrace T2 lies $23 \mathrm{~m}$ above the modern river and consists of $5 \mathrm{~m}$ of fluvial gravel and $\sim 10 \mathrm{~m}$ of fluvial sand in the Luoguogou section. Terrace T1, consisting of fluvial gravel overlain by fluvial silt, is not studied here because it is poorly exposed and mostly occupied by buildings of Lanzhou city. Based on paleomagnetic and optically-stimulated-luminescence (OSL) dating of the base of loess-paleosol sequences, the ages of these terraces have been determined as 0.05 Ma (T2), 0.14 Ma (T3), 0.86 Ma (T4), 0.96 Ma (T5), 1.05 Ma (T6), 1.24 Ma (T7), 1.5 Ma (T8), and $1.7 \mathrm{Ma}$ (T9) [10,11,38].

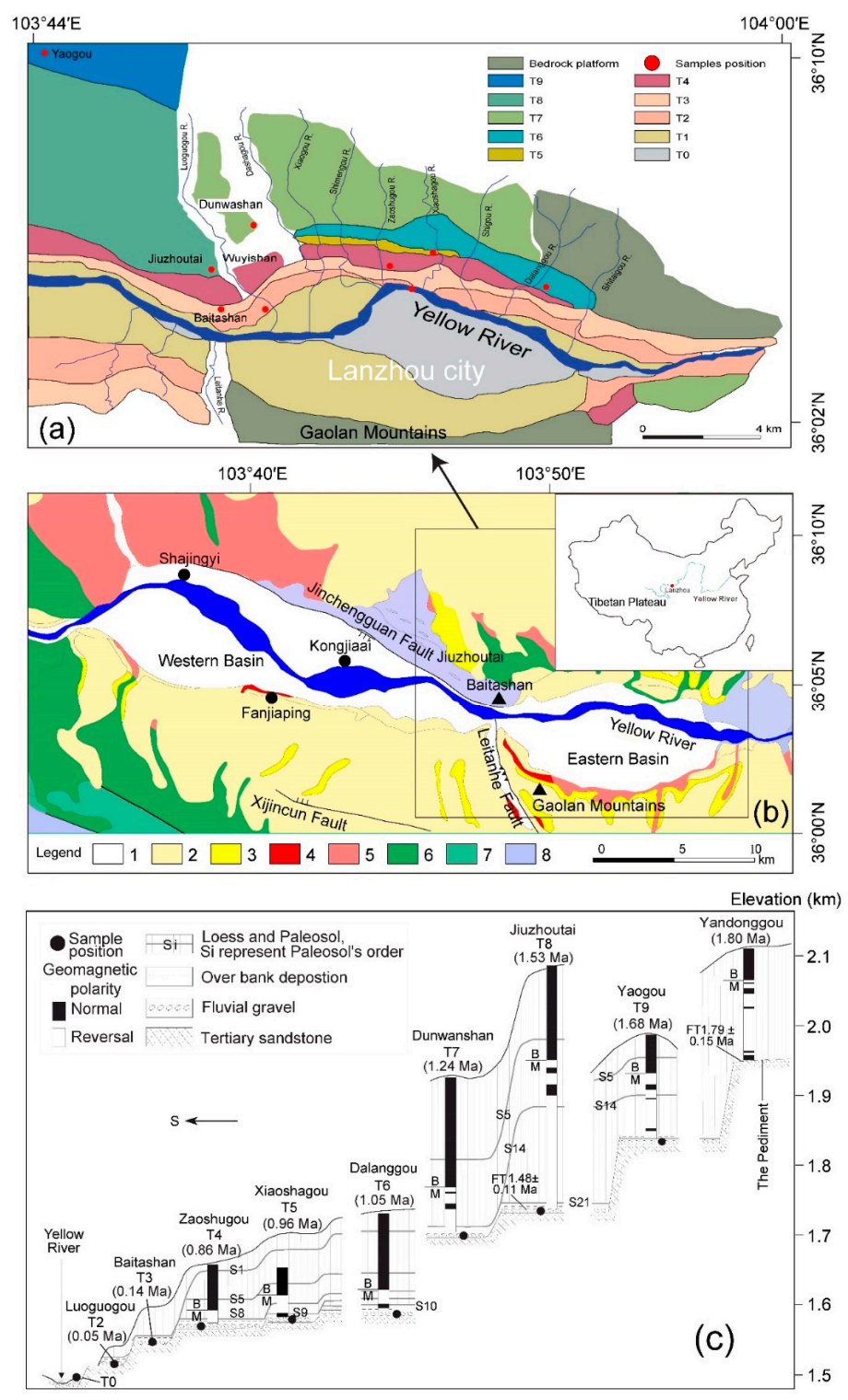

Figure 1. Yellow River terraces in the Lanzhou area. (a) Terraces distribution and sample location (modified from [10,38]). (b) Geological map of the Lanzhou area (modified from [19,21]). Geological units: 1: Holocene fluvial sediments; 2-3: Pleistocene loess-paleosol sequence; 4: Wuquan fluvial gravel formation; 5: Tertiary sandstone and glutenite; 6: Cretaceous purplish-red sandstone and greyish green siltstone; 7: Ordovician greyish green andesite and meta-andesite; 8: Precambrian basement. (c) Syntheses of stratigraphic and chronological data from loess-paleosol sequences covering terrace surfaces. The terraces' ages were obtained by measuring the magnetostratigraphy (T9-T4) and optically stimulated luminescence (OSL, T3-T2) dating of loess-paleosol sequences covering these terraces (modified from [10,38]). 


\section{Sampling and Methods}

Provenance analysis was carried out on eight sand samples collected in the eastern Lanzhou basin from alluvial terraces T9 to T2, and on one modern sand sample (T0) collected from an active bar on the Yellow River bed at Lanzhou (Figure 1a).

From each sample, heavy minerals were separated using the dense liquid tribromomethane (density $2.89 \mathrm{~g} / \mathrm{cm} 3$ ). Heavy-mineral separates were analyzed by QEMSCAN at Colorado School of Mines (Golden, CO, USA), following the procedure described in detail in [39-41]. From 290 to 398 heavy-mineral grains were counted in each sample. For composite grains including more than one mineral, the QEMSCAN determines the surface area percentage of each (Figure 2), thus providing full information on all components.

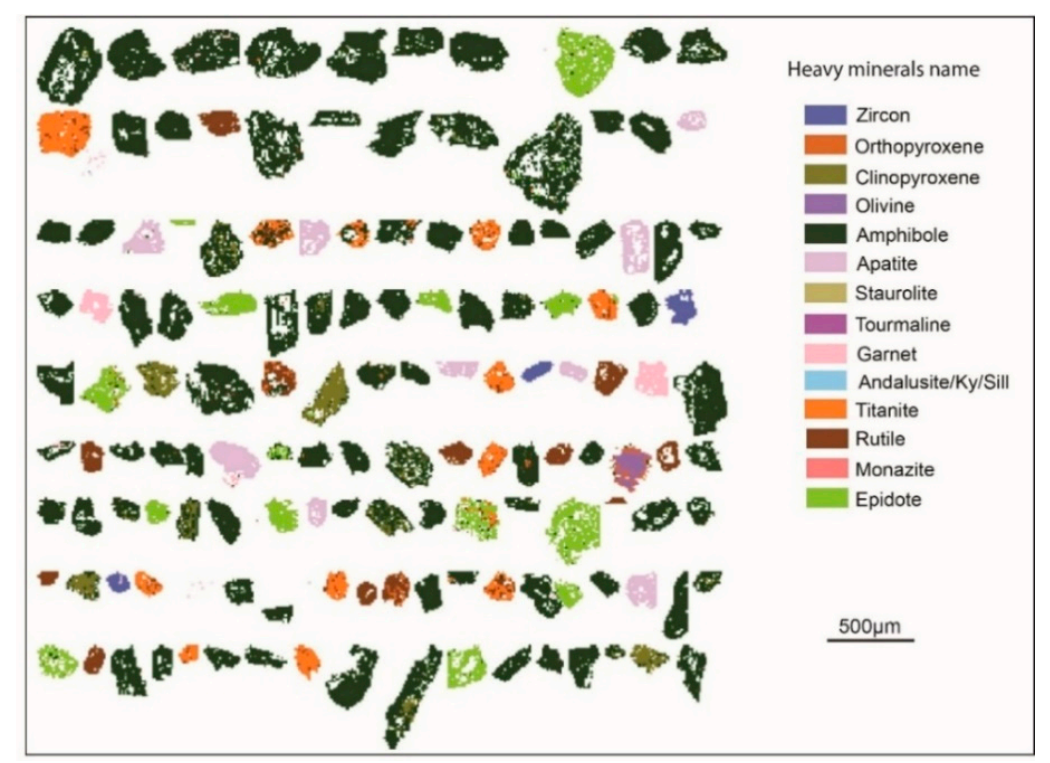

Figure 2. QEMSCAN image of heavy minerals in the modern Yellow River sample T0. Ky = Kyanite, Sill $=$ Sillimanite

The concentration of major and trace elements, including REE (rare earth elements) are widely considered as useful tracers of provenance [42-46]. Geochemical analyses were carried out on a 30-40 mg aliquot of each bulk sample crushed in an agate mortar, weighed into an airtight Teflon decomposer, and moistened with a little extra-pure water. Next, we added $1 \mathrm{~mL} \mathrm{HNO}_{3}$ and $1 \mathrm{~mL}$ $\mathrm{HF}$ in Teflon containers left in ultrasonic bath for over $20 \mathrm{~min}$, and the samples were steamed nearly dry on a heating plate at $150{ }^{\circ} \mathrm{C}$ After repeating the operation three times, the residues placed in a stainless-steel pot with $2 \mathrm{~mL} \mathrm{HNO}_{3}$ and $3 \mathrm{~mL}$ extra-pure water were heated in oven at $\sim 150{ }^{\circ} \mathrm{C}$ for over $24 \mathrm{~h}$. The concentration of chemical elements was determined by LA-ICP-MS using Agilent 7700X and Photon Machine Analyte 193nm at Key Laboratory of Mineral Resources in Western China, Lanzhou University (Lanzhou, China).

Grain-size analyses on bulk samples were carried out by Laser Diffraction Particle Size Analyzer at the Key Laboratory of Western China's Environment Systems (Ministry of Education) of Lanzhou University. All samples were air-dried and analyzed by a Mastersizer 2000 produced by Malvern Instruments Ltd. (Malvern, UK) with Hydro2000G automatic sampler. The measuring range is from 0.02 to $2000 \mu \mathrm{m}$, and the median particle size D50 has an accuracy of $\pm 1 \%$. 


\section{Results}

Different heavy-mineral assemblages in superposed Yellow River terraces of the Lanzhou area, together with varying REE patterns, indicate major provenance changes through time.

\subsection{Heavy-Mineral Assemblages}

Transparent heavy-mineral suites in modern Yellow River sand and in Pleistocene to Holocene terraces are invariably dominated by amphibole (46-58\%) and epidote (22-29\%) (Figure 3a, Table 1). The abundance of amphibole indicates prominent contributions from basement rocks [24,47], with the amphibole series forming in a wide range of temperature and pressure conditions in igneous and metamorphic rocks [48]. A ratio of amphibole versus total heavy minerals has been used to reflect past changes in the origin of loess from the central Chinese Loess Plateau [49]. Because more than $73 \%$ of the heavy-mineral fraction is composed of amphibole plus epidote in Yellow River terraces, we here use the ratio between these two dominant minerals as a tracer of provenance change. Amphibole accounts for less than $50 \%$ of the assemblage in terraces T8 and T3-T2 as well as in T0, whereas epidote displays peak abundance in terraces T3 and T2 where the amphibole/epidote ratio is close to 1 (1.01-1.08 versus 1.5-2.7 in older terraces).

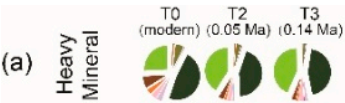

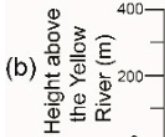

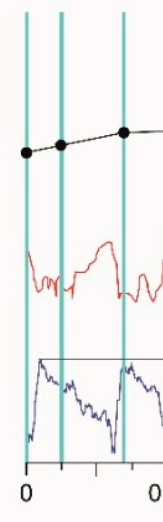

(d)
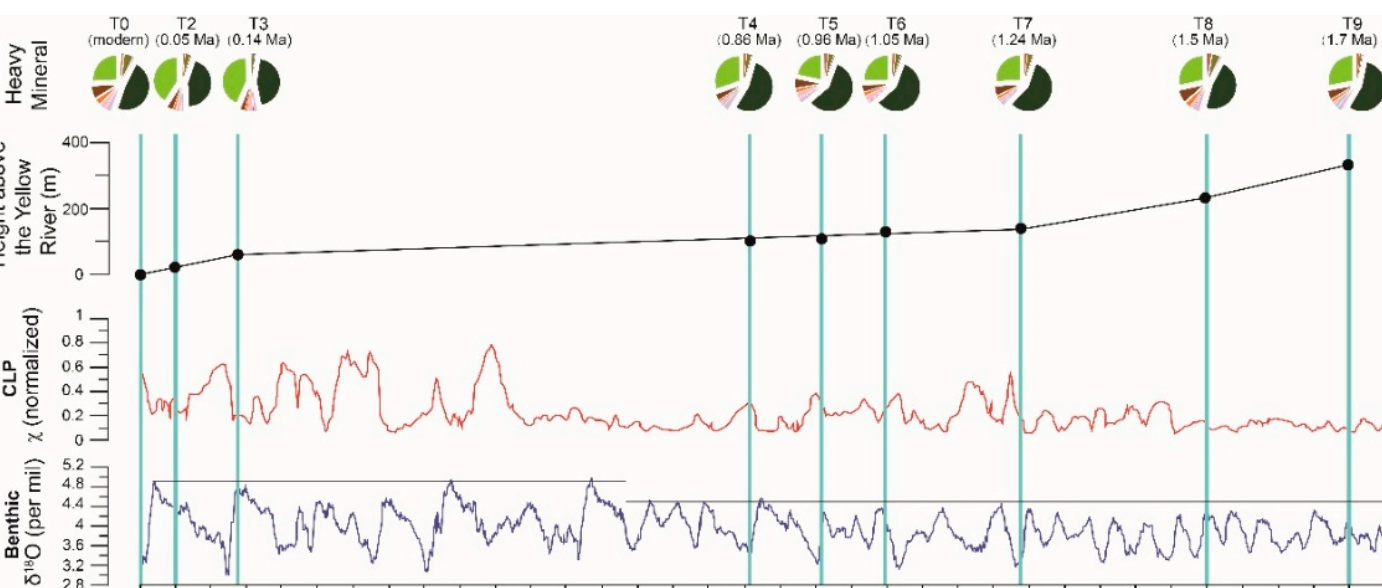

Figure 3. Comparison between heavy-mineral spectra from Yellow River terraces and the paleoclimatic record. (a) Heavy-mineral data from Yellow River terraces in the Lanzhou area. (b) Correlation between formation age of Yellow River terraces and height above the river (mod. from [10,38]). The less steep slope between T7 and T3 indicates lower rates of rock uplift and river incision at that time. (c) Variations of the East Asian summer monsoon during the past $1.8 \mathrm{Ma}$, based on the stacked magnetic susceptibility (X) records on the Chinese Loess Plateau (CLP) [50]. (d) Variations of global ice volume during the past $1.8 \mathrm{Ma}$, based on the benthic oxygen-isotope record [51]. Mineral color-code as in Figure 2. 
Table 1. Heavy-mineral assemblages in samples from the Yellow River terraces in the Lanzhou area in volume\% (data from [52])

\begin{tabular}{|c|c|c|c|c|c|c|c|c|c|c|c|c|c|c|c|}
\hline $\begin{array}{l}\text { Sample } \\
\text { Number }\end{array}$ & Age & Zircon & Opx \# & Cpx ${ }^{\#}$ & Olivine & Amphibole & Apatite & $\begin{array}{l}\text { Andalusite } \\
/ \mathrm{Ky} / \text { Sill }^{\#}\end{array}$ & Staurolite & Tourmaline & Garnet & Titanite & Rutile & Monazite & Epidote \\
\hline T9* & $1.70 \mathrm{Ma}$ & 0 & 2 & 1 & 0 & 55 & 3 & 2 & 0 & 0 & 2 & 2 & 5 & 0 & 28 \\
\hline T8 & $1.50 \mathrm{Ma}$ & 0 & 2 & 5 & 0 & 46 & 4 & 0 & 0 & 0 & 2 & 3 & 8 & 0 & 29 \\
\hline T7 & $1.24 \mathrm{Ma}$ & 0 & 2 & 3 & 1 & 57 & 1 & 1 & 0 & 0 & 2 & 2 & 6 & 0 & 26 \\
\hline T6 & $1.05 \mathrm{Ma}$ & 1 & 2 & 3 & 1 & 58 & 1 & 0 & 0 & 0 & 4 & 2 & 4 & 0 & 25 \\
\hline T5 & $0.96 \mathrm{Ma}$ & 0 & 1 & 3 & 1 & 58 & 2 & 0 & 0 & 0 & 3 & 2 & 6 & 0 & 22 \\
\hline $\mathrm{T} 4$ & $0.86 \mathrm{Ma}$ & 0 & 2 & 3 & 0 & 54 & 3 & 1 & 0 & 0 & 1 & 1 & 4 & 0 & 30 \\
\hline T3 & $0.14 \mathrm{Ma}$ & 0 & 0 & 2 & 0 & 44 & 2 & 0 & 0 & 0 & 3 & 1 & 3 & 0 & 44 \\
\hline $\mathrm{T} 2$ & $0.05 \mathrm{Ma}$ & 0 & 1 & 3 & 0 & 44 & 1 & 0 & 0 & 0 & 3 & 1 & 4 & 0 & 41 \\
\hline T0 & modern & 1 & 1 & 6 & 0 & 47 & 3 & 0 & 0 & 0 & 4 & 4 & 8 & 0 & 26 \\
\hline
\end{tabular}

* The name Tx stands for Yellow River terrace sample where $\mathrm{x}$ is a terrace number, T0 is the modern Yellow River bed sample. \# Opx = Orthopyroxene; Cpx = Clinopyroxene; Ky = Kyanite;

Sill = Sillimanite. 


\subsection{Rare Earth Elements}

The total REE ( $\sum$ REE) content in Yellow River terraces varies widely from 46 to $116 \mathrm{ppm}$. In chondrite-normalized REE diagrams (Figure 4, Table 2), all samples show enrichment in light rare earth elements (LREE, 43-108 ppm) and depletion in heavy rare earth elements (HREE, 3.4-8.2 ppm), with negative $\mathrm{Eu}\left(\mathrm{Eu} / \mathrm{Eu}^{*}=0.67-0.84\right)$ and $\mathrm{Ce}\left(\mathrm{Ce} / \mathrm{Ce}^{*}=0.86-0.90\right)$ anomalies.

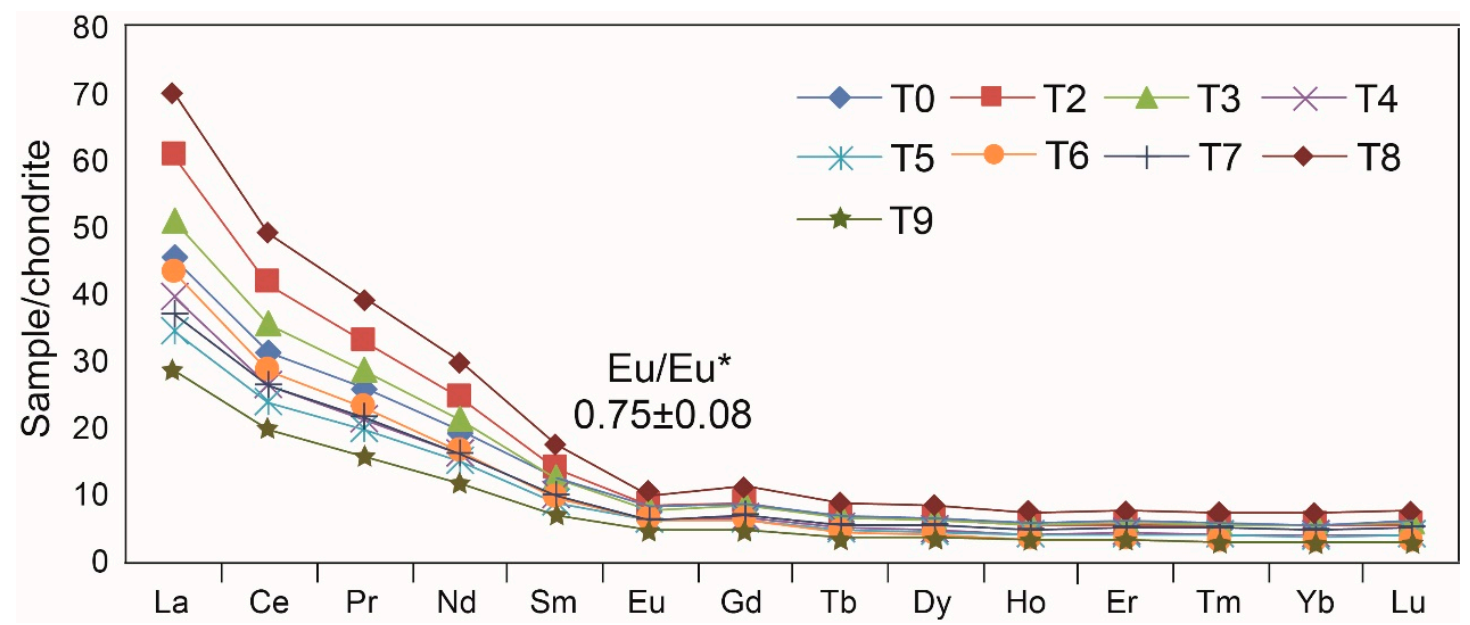

Figure 4. Chondrite-normalized REE patterns for Yellow River terraces of the Lanzhou area.

Table 2. Rare earth elements concentrations (ppm) in sediments from the Yellow River terraces in the Lanzhou area

\begin{tabular}{|c|c|c|c|c|c|c|c|c|c|c|c|c|c|c|c|}
\hline $\begin{array}{l}\text { Sample } \\
\text { Number }\end{array}$ & Age & La & $\mathrm{Ce}$ & Pr & Nd & $\mathrm{Sm}$ & Eu & Gd & $\mathrm{Tb}$ & Dy & Ho & Er & $\mathrm{Tm}$ & $\mathrm{Yb}$ & Lu \\
\hline T9 * & $1.70 \mathrm{Ma}$ & 10.470 & 18.676 & 2.140 & 8.260 & 1.580 & 0.383 & 1.402 & 0.210 & 1.306 & 0.250 & 0.759 & 0.100 & 0.677 & 0.105 \\
\hline $\mathrm{T} 8$ & $1.50 \mathrm{Ma}$ & 25.715 & 47.243 & 5.410 & 21.115 & 3.985 & 0.832 & 3.412 & 0.497 & 3.068 & 0.597 & 1.839 & 0.254 & 1.744 & 0.280 \\
\hline $\mathrm{T} 7$ & $1.24 \mathrm{Ma}$ & 13.480 & 24.928 & 2.934 & 11.420 & 2.219 & 0.533 & 2.031 & 0.312 & 2.024 & 0.396 & 1.211 & 0.172 & 1.175 & 0.194 \\
\hline T6 & $1.05 \mathrm{Ma}$ & 15.838 & 27.250 & 3.112 & 11.699 & 2.141 & 0.519 & 1.789 & 0.238 & 1.389 & 0.257 & 0.744 & 0.103 & 0.687 & 0.105 \\
\hline $\mathrm{T} 5$ & $0.96 \mathrm{Ma}$ & 12.582 & 22.681 & 2.666 & 10.430 & 2.025 & 0.515 & 1.843 & 0.269 & 1.664 & 0.316 & 0.966 & 0.132 & 0.895 & 0.144 \\
\hline $\mathrm{T} 4$ & $0.86 \mathrm{Ma}$ & 14.512 & 24.976 & 2.892 & 11.228 & 2.202 & 0.533 & 1.939 & 0.281 & 1.733 & 0.331 & 1.016 & 0.138 & 0.937 & 0.150 \\
\hline $\mathrm{T} 2$ & $0.05 \mathrm{Ma}$ & 22.269 & 39.731 & 4.508 & 17.364 & 3.184 & 0.731 & 2.630 & 0.375 & 2.314 & 0.450 & 1.314 & 0.189 & 1.268 & 0.203 \\
\hline T0 & modern & 16.664 & 29.551 & 3.470 & 13.511 & 2.640 & 0.622 & 2.320 & 0.334 & 2.048 & 0.393 & 1.193 & 0.164 & 1.081 & 0.188 \\
\hline \multicolumn{2}{|c|}{ chondrite } & 0.367 & 0.957 & 0.137 & 0.711 & 0.231 & 0.087 & 0.306 & 0.058 & 0.381 & 0.0851 & 0.249 & 0.0356 & 0.248 & 0.0381 \\
\hline
\end{tabular}

* The name Tx stands for Yellow River terrace sample where $\mathrm{x}$ is a terrace number, T0 is the modern Yellow River bed sample.

REE curves are all similar, with minimum values for the oldest terrace $\mathrm{T} 9$ and maximum values for terrace T8. REE contents are relatively high for both terraces T3 and T2 (Figure 4). For the interpretation of REE concentration; however, it must be kept in mind that REE are preferentially hosted in ultra-dense minerals such as monazite, and their abundance in sediments is consequently strongly affected by hydraulic-sorting processes [53].

\section{Discussion}

The mineralogical and geochemical fingerprints of siliciclastic sediments are mainly controlled by the lithology of source rocks, with superposed effects associated with climatic conditions in the catchment and hydraulic sorting during erosion, transport, and deposition [9,54].

Most of the river sediments have similar and uniform REE patterns displaying enrichment in light REE [55,56] which is inherited from source rocks, confirming that the sediments are not anthropogenically polluted [57,58]. Heavy-mineral assemblages in Yellow River terraces and geochemical data suggest that changes in sediment composition took place between terraces T9 and T8, and between terraces T4 and T3. The provenance changes cannot be discounted as a 
grain-size effect because T3 and T2 have similar composition despite their markedly different grain-size distributions (Figure 5). This is confirmed by the principal-component diagram shown in Figure 6, where terraces T3 and T2 plot on the right side of the PC1 component, accounting for $\sim 82 \%$ of data variance. Principal-component analysis also suggest that terrace T8 and modern fluvial sand T0 are distinguished from other samples on PC2, accounting for $\sim 15 \%$ of data variance. This reflects at least in part the slightly lower content in hornblende relative to samples T9 and T7-T4. Some studies in Europe have shown that higher uplift rates may decrease the preservation of climate-controlled fluvial terraces, whereas moderate to low uplift rates will enable their preservation [59-61]. Accurate field investigations have failed to find any Yellow River terrace in the Lanzhou area formed between $0.86 \mathrm{Ma}$ and 0.14 Ma [10]. However, it is noteworthy that this provenance change took place between 0.86 and $0.14 \mathrm{Ma}$, a long period of decreased tectonic activity when river terraces were not formed- or were formed but were not preserved-in the Lanzhou basin [10] (Figure 3b). For this reason, we could not more precisely constrain the age of such a compositional change.

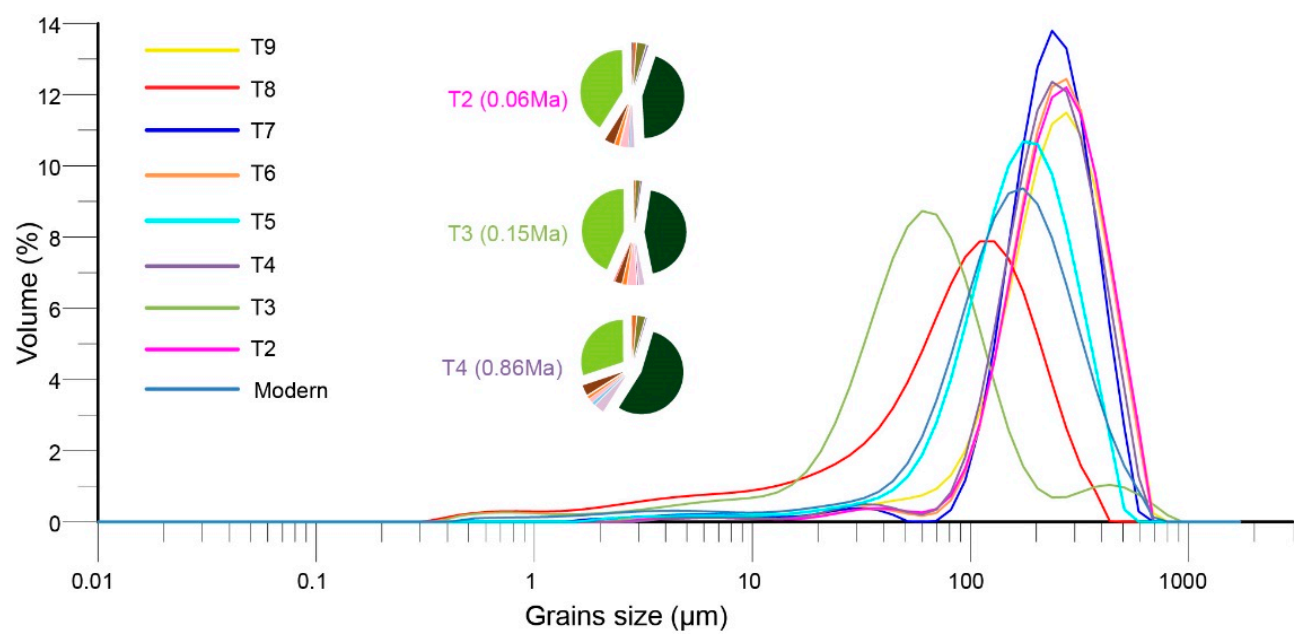

Figure 5. Grain-size curves of sediment samples from Yellow River terraces of the Lanzhou area, and heavy-mineral spectra for terraces T2, T3, and T4. Mineral color-code as in Figure 2.

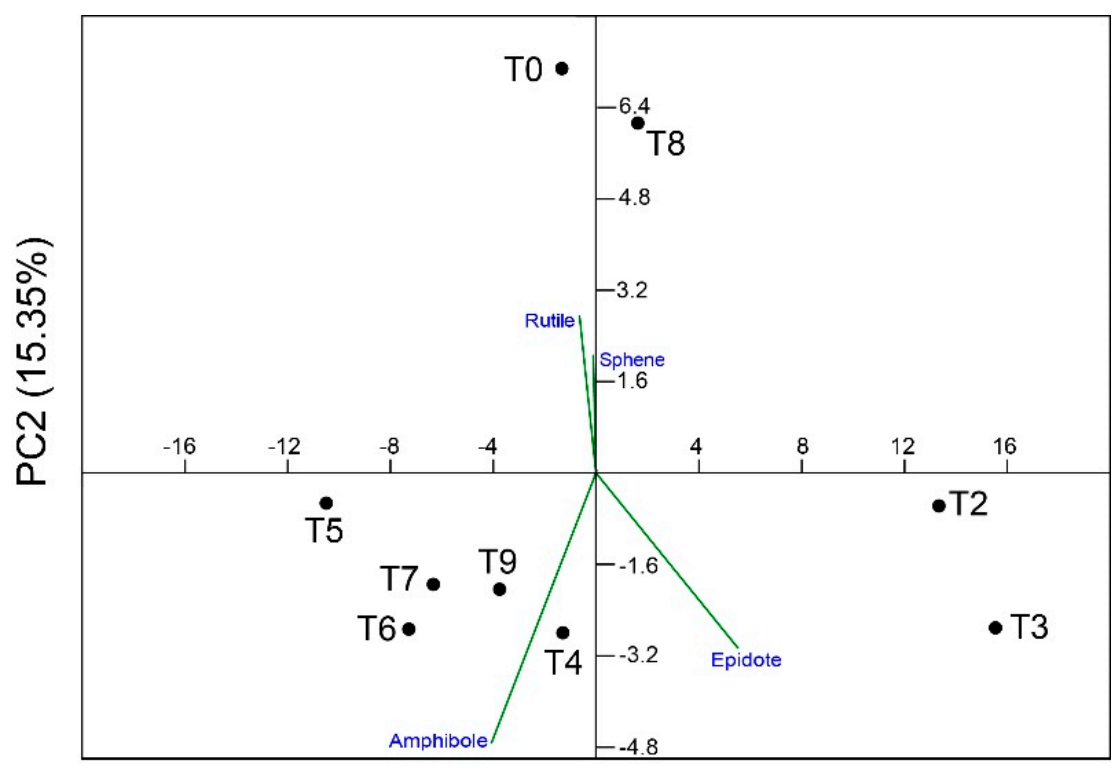

PC1 (82.05\%)

Figure 6. Principal component analysis of heavy-mineral assemblages in Yellow River terraces of the Lanzhou area. 
Before 1.45 Ma (terraces T8 and T9), the East Asian summer monsoon was relatively stable, as documented by magnetic-susceptibility data on Chinese loess [50] (Figure 3c), and there is no evidence of large variations in ice volume [51] (Figure 3d). This speaks against climate change as a main cause for the change in heavy-mineral assemblages and geochemical signatures observed between terraces T9 and T8. In this time window-i.e., between 1.7 and $1.5 \mathrm{Ma}$ - the Yellow River rapidly incised its talweg by as much as $100 \mathrm{~m}$. If this was not triggered by climatic change, then active tectonic uplift remains as the most plausible cause [62].

Between 1.24 Ma (terrace T7) and 0.86 Ma (terrace T4), the Yellow River course was shorter, its drainage basin smaller, and its sediment load notably less than today $[12,13,63]$. The timing of major paleogeographic change took place during, and in the final part of the so-called "mid-Pleistocene climatic revolution" (or early-middle Pleistocene transition; 1.4-0.424 Ma), characterized by a progressive increase in the amplitude of climatic oscillations $[64,65]$. At that time, the East Asian summer monsoon intensified and the amplitude of ice-volume variation between glacial and interglacial stages increased, as documented by magnetic-susceptibility data on Chinese loess [50,51] (Figure 3c,d). Increased glacial erosion may have enhanced sediment fluxes [66-68] at that time, when a phase of decreased rock uplift and deformation in the Lanzhou area is suggested by the decrease in incision rates as highlighted in Figure 3b. Tectonic control is unlikely for this time period [62], during which heavy-mineral and geochemical signatures have remained remarkably constant.

After $0.86 \mathrm{Ma}$, the change in heavy-mineral assemblages and geochemical fingerprints observed between terraces T4 $(0.86 \mathrm{Ma})$ and T3 $(0.14 \mathrm{Ma})$ may be explained with the stepwise addition of large areas to the upper reaches of the Yellow River by headward erosion $[12,63]$. This scenario is consistent with the increase in precipitations as a consequence of enhanced East Asian Summer Monsoon [50] and with the increased amplitude in ice-volume variation [51]. Between $\sim 0.5$ and $0.1 \mathrm{Ma}$, Yellow River sediment fluxes markedly increased, while the Gonghe basin, the Tongde basin, and the Jungong basin were successively incorporated in the Yellow River drainage system $[4,12,13]$.

\section{Conclusions}

The study of heavy-mineral assemblages and REE patterns characterizing Yellow River terraces in the Lanzhou area reveals two notable provenance changes, from $\sim 1.7 \mathrm{Ma}$ (terrace T9) to $\sim 1.5 \mathrm{Ma}$ (terrace T8) and from $\sim 0.86 \mathrm{Ma}$ (terrace T4) to $\sim 0.14 \mathrm{Ma}$ (terrace T3). Two paleogeographic reorganizations took place during those time intervals, both associated with phases of expansion of the upper Yellow River catchment and consequently increased sediment fluxes.

The height difference of $\sim 100 \mathrm{~m}$ between terraces T9 and T8 indicates rapid incision during the early Pleistocene (early Calabrian), suggesting that the first shift was triggered tectonically by a phase of rapid uplift of the northeastern Tibetan plateau. The second reorganization took place during the final part of the middle Pleistocene transition (late Calabrian), when the East Asian summer monsoon intensified and the amplitude of ice-volume variation between glacial and interglacial stages increased. River incision was much slower at this time, indicating that this second, major reorganization was chiefly climatically controlled.

Author Contributions: Writing-Original Draft Preparation by Z.W. and H.Z.; Writing-Review and Editing by E.G., J.N., and S.A.; Data Analysis and Figures by Z.W., H.Z., and W.P.; Sampling by W.P., X.H., B.P., and J.N.; Experiments by Z.W., W.P., H.Z., and K.P.

Funding: This work was funded by the Second Tibetan Plateau Scientific Expedition (grant no. 2019QZKK0704), the National Natural Science Foundation of China (grant no. 41761144063, 41672157, 41807427, 41907073, 41422204), the Open Foundation of MOE Key Laboratory of Western China's Environmental System, Lanzhou University (grant no. lzujbky-2018-kb01, lzujbky-2019-kb01), the Open Project of Key Laboratory for Magnetism and Magnetic Materials of the Ministry of Education, Lanzhou University (grant no. LZUMMM2018007), the State Scholarship Fund organized by China Scholarship Council (grant no. 201806180066), and by MIUR-Dipartimenti di Eccellenza 2018-2022, Department of Earth and Environmental Sciences, University of Milano-Bicocca.

Acknowledgments: Heartfelt thanks to Assistant Editor and three reviewers, whose comments helped us to improve on the paper significantly. 
Conflicts of Interest: The authors declare no conflict of interest.

\section{References}

1. Milliman, J.D.; Meade, R.H. World-wide delivery of river sediment to the oceans. J. Geol. 1983, 91, 1-21. [CrossRef]

2. Ren, M.E. Sediment discharge of the Yellow River, China: Past, present and future-A synthesis. Acta Oceanol. Sin. 2015, 34, 1-8. [CrossRef]

3. Li, J.J. The environmental effects of the uplift of the Qinghai-Xizang Plateau. Quat. Sci. Rev. 1991, 10, 479-483. [CrossRef]

4. Harkins, N.; Kirby, E.; Heimsath, A.; Robinson, R.; Reiser, U. Transient fluvial incision in the headwaters of the Yellow River, northeastern Tibet, China. J. Geophys. Res. 2007, 112, F03S04. [CrossRef]

5. Lease, R.O.; Burbank, D.W.; Gehrels, G.E.; Wang, Z.C.; Yuan, D.Y. Signatures of mountain building: Detrital zircon $\mathrm{U} / \mathrm{Pb}$ ages from northeastern Tibet. Geology 2007, 35, 239-242. [CrossRef]

6. Hu, Z.B.; Pan, B.T.; Guo, L.Y.; Vandenbergheb, J.; Liu, X.P.; Wang, J.P.; Fan, Y.L.; Mao, J.W.; Gao, H.S. Rapid fluvial incision and headward erosion by the Yellow River along the Jinshaan gorge during the past $1.2 \mathrm{Ma}$ as a result of tectonic extension. Quat. Sci. Rev. 2016, 133, 1-14. [CrossRef]

7. Hu, Z.B.; Pan, B.T.; Bridgland, D.; Vandenberghe, J.; Guo, L.Y.; Fan, Y.L.; Westaway, R. The linking of the upper-middle and lower reaches of the Yellow River as a result of fluvial entrenchment. Quat. Sci. Rev. 2017, 166, 324-338. [CrossRef]

8. Wang, W.T.; Zhang, P.Z.; Liu, C.K.; Zheng, D.W.; Yu, J.X.; Zheng, W.J.; Wang, Y.Z.; Zhang, H.P.; Chen, X.Y. Pulsed growth of the West Qinling at $30 \mathrm{Ma}$ in northeastern Tibet: Evidence from Lanzhou Basin magneostratigraphy and provenance. J. Geophys. Res.-Solid Earth 2016, 121, 7754-7774. [CrossRef]

9. Pang, H.L.; Pan, B.T.; Garzanti, E.; Gao, H.S.; Zhao, X.; Chen, D.B. Mineralogy and geochemistry of modern Yellow River sediments: Implications for wreathing and provenance. Chem. Geol. 2018, 488, 76-86. [CrossRef]

10. Pan, B.T.; Su, H.; Hu, Z.B.; Hu, X.F.; Gao, H.S.; Li, J.J.; Kirby, E. Evaluating the role of climate and tectonics during non-steady incision of the Yellow River: Evidence from a 1.24 Ma terrace record near Lanzhou, China. Quat. Sci. Rev. 2009, 28, 3281-3290. [CrossRef]

11. Pan, B.T. Problems on the Development of the Yellow River and Uplift of Qinghai-Xizang Plateau. Ph.D. Thesis, Lanzhou University, Lanzhou, China, 1991. (In Chinese).

12. Craddock, W.H.; Kirby, E.; Harkins, W.N.; Zhang, H.P.; Shi, X.H.; Liu, J.H. Rapid fluvial incision along the Yellow River during headward basin integration. Nat. Geosci. 2010, 3, 209-213. [CrossRef]

13. Perrineau, A.; Van Der Woerd, J.; Gaudemer, Y.; Zeng-Liu, J.; Pik, P.; Tapponnier, P.; Thuizat, R.; Zheng, R.Z. Incision rate of the Yellow River in Northeastern Tibet constrained by ${ }^{10} \mathrm{Be}$ and ${ }^{26} \mathrm{Al}$ cosmogenic isotope dating of fluvial terraces: Implications for catchment evolution and plateau building. Geol. Soc. Lond. Spec. Publ. 2011, 353, 189-219. [CrossRef]

14. Kong, P.; Jia, J.; Zheng, Y. Time constraints for the Yellow River traversing the Sanmen Gorge. Geochem. Geophy. Geosyst. 2014, 15, 395-407. [CrossRef]

15. Zhang, J.; Huang, W.W.; Liu, M.G.; Zhou, Q. Drainage basin weathering and major element transport of two larger Chinese river (Huanghe and Changjiang). J. Geophy. Res. 1990, 95, 13277-13288. [CrossRef]

16. Yang, S.Y.; Li, C.X. Research progress in REE trace for sediment source. Adv. Earth Sci. 1999, 14, $164-167$. (In Chinese)

17. Yang, S.Y.; Li, C.X.; Jung, H.S.; Lee, H.J. Discrimination of geochemical compositions between the Changjiang and the Huanghe sediments and its application for the identification of sediment source in the Jiangsu coastal plain, China. Mar. Geol. 2002, 186, 229-241. [CrossRef]

18. Nie, J.S.; Stevens, T.; Rittner, M.; Stockli, D.; Garzanti, E.; Limonta, M.; Bird, A.; Andò, S.; Vermeesch, P.; Saylor, J.; et al. Loess Plateau storage of northeastern Tibetan Plateau-derived Yellow River sediment. Nat. Commun. 2015, 6, 8511. [CrossRef] [PubMed]

19. Pan, B.T.; Pang, H.L.; Gao, H.S.; Garzanti, E.; Zou, Y.; Liu, X.P.; Li, F.Q.; Jia, Y.X. Heavy-mineral analysis and provenance of Yellow River sediments around the China Loess Plateau. J. Asian Earth Sci. 2016, 127, 1-11. [CrossRef]

20. Jin, B.F.; Wang, M.Y.; Yue, W.; Zhang, L.N.; Wang, Y.J. Heavy Mineral Variability in the Yellow River Sediments as Determined by the Multiple-Window Strategy. Minerals 2019, 9, 85. [CrossRef] 
21. Guo, B.H.; Liu, S.P.; Peng, T.J.; Ma, Z.H.; Feng, Z.T.; Li, M.; Li, X.M.; Li, J.J.; Song, C.H.; Zhao, Z.J.; et al. Late Pliocene establishment of exorheic drainage in the northeastern Tibetan Plateau as evidenced by the Wuquan Formation in the Lanzhou Basin. Geomorphology 2018, 303, 271-283. [CrossRef]

22. Che, X.D.; Li, G.J. Binary sources of loess on the Chinese Loess Plateau revealed by U-Pb ages of zircon. Quat. Res. 2013, 80, 545-551. [CrossRef]

23. Licht, A.; Pullen, A.; Kapp, P.; Abell, J.; Giesler, N. Eolian cannibalism: Reworked loess and fluvial sediment as the main sources of the Chinese Loess Plateau. Geol. Soc. Am. Bull. 2016, 128, 944-956. [CrossRef]

24. Garzanti, E.; Andò, S. Plate tectonics and heavy-mineral suites of modern sands. Dev. Sedimentol. 2007, 58, 741-763. [CrossRef]

25. Morton, A.C.; Hallsworth, C. Stability of detrital heavy minerals during burial diagenesis. Dev. Sedimentol. 2007, 58, 215-245. [CrossRef]

26. Taylor, S.R.; McLennan, S.M. The Continental Crust: Its Composition and Evolution; Blackwell Scientific Publications: Oxford, UK, 1985; p. 312.

27. Cullers, R.L. Implication of elemental concentrations for provenance, redox conditions, and metamorphic studies of shales and limestones near Pueblo, CO, USA. Chem. Geol. 2002, 191, 305-327. [CrossRef]

28. Moreno, T.; Querol, X.; Castillo, S.; Alastuey, A.; Cuevas, E.; Herrmann, L.; Mounkaila, M.; Elvira, J.; Gibbons, W. Geochemical variations in aeolian mineral particles from the Sahara-Sahel Dust Corridor. Chemosphere 2006, 65, 261-270. [CrossRef] [PubMed]

29. Roy, P.D.; Smykatz-Kloss, W. REE geochemistry of the recent playa sediments from the Thar desert, India: An implication to play a sediment provenance. Chemie der Erde-Geochemistry 2007, 67, 55-68. [CrossRef]

30. Castillo, S.; Moreno, T.; Querol, S.; Alastuey, A.; Cuevas, E.; Herrmann, L.; Mounkaila, M.; Gibbons, W. Trace element variation in size-fractionated African desert dusts. J. Arid Environ. 2008, 72, 1034-1045. [CrossRef]

31. Kasper-Zublillaga, J.J.; Acevedo-Vargas, B.; Bermea, O.M.; Zamora, G.O. Rare earth elements of the Altar Desert dune and coastal sands, Northwestern Mexico. Chemie der Erde-Geochemistry 2008, 68, 45-59. [CrossRef]

32. Wang, P.; Jiang, H.C.; Yuan, D.Y.; Liu, X.W.; Zhang, B. Optically stimulated luminescence dating of sediments from the Yellow River terraces in Lanzhou: Tectonic and climatic implications. Quat. Geochronol. 2010, 5, 181-186. [CrossRef]

33. Miao, Y.F.; Wu, F.L.; Herrmann, M.; Yan, X.L.; Meng, Q.Q. Late early Oligocene East Asian summer monsoon in the NE Tibetan Plateau: Evidence from a palynological record from the Lanzhou Basin China. J. Asian Earth Sci. 2013, 75, 46-57. [CrossRef]

34. Yue, L.P.; Heller, F.; Qiu, Z.X.; Zhang, L.; Jie, G.P.; Qiu, Z.D.; Zhang, Y.X. Magnetostratigraphy and paeleo-environmental record of Tertiary deposits of Lanzhou Basin. Chin. Sci. Bull. 2001, 46, 770-773. [CrossRef]

35. Zhang, L.Y. Preliminary study on Quaternary geology of Lanzhou valley basin. J. Lanzhou Univ. 1962, 2, 89-98. (In Chinese)

36. Chen, J.F. Study on Landform Development Model at Longzhong Basin since Late Pliocene. Master's Thesis, Lanzhou University, Lanzhou, China, 2010. (In Chinese).

37. Zhu, J.J.; Zhong, W.; Li, J.J.; Cao, J.X.; Wang, J.L. The oldest eolian loess deposition in the Longxi Basin-Yandonggou profile in Lanzhou. Sci. Geogr. Sin. 1996, 16, 365-369. (In Chinese)

38. Hu, X.F.; Kirby, E.; Pan, B.T.; Granger, D.E.; Su, H. Cosmogenic burial ages reveal sediment reservoir dynamics along the Yellow River, China. Geology 2011, 39, 839-842. [CrossRef]

39. Nie, J.S.; Peng, W.B.; Pfaff, K.; Möller, A.; Garzanti, E.; Andò, S.; Stevens, T.; Bird, A.; Chang, H.; Song, Y.G.; et al. Controlling factors on heavy mineral assemblages in Chinese loess and Red Clay. Palaeogeogr. Palaeoclimatol. Palaeoecol. 2013, 381-382, 110-118. [CrossRef]

40. Nie, J.S.; Peng, W.B. Automated SEM-EDS heavy mineral analysis reveals no provenance shift between glacial loess and interglacial paleosol on the Chinese Loess Plateau. Aeolian Res. 2014, 13, 71-75. [CrossRef]

41. Peng, W.B.; Wang, Z.; Song, Y.G.; Pfaff, K.; Luo, Z.; Nie, J.S.; Chen, W.H. A comparison of heavy mineral assemblage between the loess and the Red Clay sequences on the Chinese Loess Plateau. Aeolian Res. 2016, 21,87-91. [CrossRef]

42. McLennan, S.M. Relationships between the trace element composition of sedimentary rocks and upper continental crust. Geochem. Geophy. Geosyst. 2001, 2, 2000GC000109. [CrossRef]

43. Yang, S.; Li, C.; Lee, C.B.; Na, T.K. REE geochemistry of suspended sediments from the rivers around the Yellow Sea and provenance indicators. Chin. Sci. Bull. 2003, 48, 1135-1139. [CrossRef] 
44. Singh, P. Major, trace and REE geochemistry of the Ganga River sediments: Influence of provenance and sedimentary processes. Chem. Geol. 2009, 266, 251-264. [CrossRef]

45. Fleet, A.J. Aqueous and sedimentary geochemistry of the rare earth elements. In Developments in Geochemistry; Elsevier: Amsterdam, The Netherlands, 1984; Volume 2, pp. 343-374.

46. Garzanti, E.; Padoan, M.; Setti, M.; López-Galindo, A.; Villa, I.M. Provenance versus weathering control on the composition of tropical river mud (southern Africa). Chem. Geol. 2014, 366, 61-74. [CrossRef]

47. Garzanti, E.; Vezzoli, G.; Andò, S.; Castiglioni, G. Petrology of rifted-margin sand (Red Sea and Gulf of Aden, Yemen). J. Geol. 2001, 109, 277-297. [CrossRef]

48. Andò, S.; Morton, A.; Garzanti, E. Metamorphic grade of source rocks revealed by chemical fingerprints of detrital amphibole and garnet. Geol. Soc. Lond. Spec. Publ. 2014, 386, 351-371. [CrossRef]

49. He, T.; Liu, L.W.; Chen, Y.; Sheng, X.F.; Ji, J.F. A seven-million-year hornblende mineral record from the central Chinese Loess Plateau. Sci. Rep. 2017, 7, 2382. [CrossRef]

50. Sun, Y.B.; Clemens, S.C.; An, Z.S.; Yu, Z.W. Astronomical timescale and palaeoclimatic implication of stacked 3.6-Myr monsoon records from the Chinese Loess Plateau. Quat. Sci. Rev. 2006, 25, 33-48. [CrossRef]

51. Lisiecki, L.E.; Raymo, M.E. A Plio-Pleistocene stack of 57 globally distributed benthic $\delta^{18} \mathrm{O}$ records. Paleoceanography 2005, 20, PA1003. [CrossRef]

52. Wang, Z.; Nie, J.S.; Wang, J.P.; Zhang, H.B.; Peng, W.B.; Garzanti, E.; Hu, X.F.; Stevens, T.; Pfaff, K.; Pan, B.T. Testing contrasting models of the formation of the upper Yellow River using heavy-mineral data from the Yinchuan Basin drill cores. Geophys. Res. Lett. 2019, 46. [CrossRef]

53. Garzanti, E.; Andò, S.; France-Lanord, C.; Vezzoli, G.; Censi, P.; Galy, V.; Najman, Y. Mineralogical and chemical variability of fluvial sediments: 1 . Bedload sand (Ganga-Brahmaputra, Bangladesh). Earth Planet. Sci. Lett. 2010, 299, 368-381. [CrossRef]

54. Garzanti, E.; Andò, S. Heavy Minerals for Junior Woodchucks. Minerals 2019, 9, 148. [CrossRef]

55. Goldstein, S.J.; Jacobsen, S.B. Rare earth elements in river waters. Earth Planet. Sci. Lett. 1988, 89, 35-47. [CrossRef]

56. Sholkovitz, E.R. Chemical evolution of rare earth elements: Fractionation between colloidal and solution phases of filtered river water. Earth Planet. Sci. Lett. 1992, 114, 77-84. [CrossRef]

57. Yang, S.Y.; Jung, H.S.; Choi, M.S.; Li, C.X. The rare earth element compositions of the Changjiang (Yangtze) and Huanghe (Yellow) river sediments. Earth Planet. Sci. Lett. 2002, 201, 407-419. [CrossRef]

58. Romero-Freire, A.; Minguez, L.; Pelletier, M.; Cayer, A.; Caillet, C.; Devin, S.; Gross, E.M.; Guérold, F.; Pain-Devin, S.; Vignati, D.A.L.; et al. Assessment of baseline ecotoxicity of sediments from a prospective mining area enriched in light rare earth elements. Sci. Total Environ. 2018, 612, 831-839. [CrossRef] [PubMed]

59. Veldkamp, A.; Van Dijke, J.J. Simulation internal and external controls on fluvial terrace stratigraphy: A qualitative comparison with the Maas record. Geomorphology 2000, 33, 225-236. [CrossRef]

60. Gibbard, P.L.; Lewin, J. River incision and terrace formation in the late Cenozoic of Europe. Tectonophysics 2009, 474, 41-55. [CrossRef]

61. Winsemann, J.; Lang, J.; Böhner, U.; Polom, U.; Brandes, C.; Roskosch, J.; Glotzbach, C.; Frechen, M. Terrace styles and timing of terrace formation in the Weser and Leine valleys, northern Germany: Response of a fluvial system to climate change and glaciations. Quat. Sci. Rev. 2015, 123, 31-57. [CrossRef]

62. Li, J.J.; Fnag, X.M.; Van der Voo, R.; Zhu, J.J.; Nicocaill, C.M.; Ono, Y.; Pan, B.T.; Zhong, W.; Wang, J.L.; Sasaki, T.; et al. Magnetostratigraphic dating of river terraces: Rapid and intermittent incision by the Yellow River of the northeastern margin of the Tibetan Plateau during the Quaternary. J. Geophys. Res.-Solid Earth 1997, 102, 10121-10132. [CrossRef]

63. Zhang, H.P.; Zhang, P.Z.; Champagnac, J.D.; Molnar, P.; Anderson, R.S.; Kirby, E.; Craddock, W.H.; Liu, S.F. Pleistocene drainage reorganization driven by the isostatic response to deep incision into the northeastern Tibetan Plateau. Geology 2014, 42, 303-306. [CrossRef]

64. Ruddiman, W.F.; Raymo, M.; McIntyre, A. Matuyama 41,000-year cycles: North Atlantic Ocean and northern hemisphere ice sheets. Earth Planet. Sci. Lett. 1986, 80, 117-129. [CrossRef]

65. Head, M.J.; Gibbard, P.L. Early-Middle Pleistocene transitions: Linking terrestrial and marine realms. Quat. Int. 2015, 389, 7-46. [CrossRef]

66. McLennan, S.M. Weathering and global denudation. J. Geol. 1993, 101, 295-303. [CrossRef] 
67. Zhou, S.Z.; Jijun, L.; Zhang, S.Q.; Zhao, J.D.; Cui, J.X. Quaternary glaciations in China. In Developments in Quaternary Sciences; Ehlers, J., Gibbard, P.L., Eds.; Elsevier: Amsterdam, The Netherlands, 2004; Volume 2, pp. 105-113.

68. Sun, J.M.; Zhu, X.K. Temporal variations in $\mathrm{Pb}$ isotopes and trace element concentrations within Chinese eolian deposits during the past 8 Ma: Implications for provenance change. Earth Planet. Sci. Lett. 2010, 290, 438-447. [CrossRef]

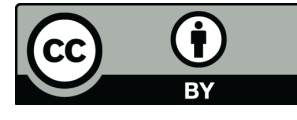

(C) 2019 by the authors. Licensee MDPI, Basel, Switzerland. This article is an open access article distributed under the terms and conditions of the Creative Commons Attribution (CC BY) license (http://creativecommons.org/licenses/by/4.0/). 